\title{
The Wesleyan Quadrilateral and Contemporary Biblical Exegesis
}

\author{
Isaac Boaheng 1
}

${ }^{1}$ Bible Society - Ghana.

\begin{abstract}
How can one discern and apply God's will and purpose for human life as revealed in Scriptures? Different scholars have answered this question from different exegetical perspectives. John Wesley, the founder of Methodism, suggested that any sound biblical exegesis must have four pillars, namely, Scripture, tradition, reason, and experience. Wesley's multifaceted approach to biblical exegesis stresses the primacy of Scripture correlated with tradition, reason and experience. This paper explores Wesley's interpretative framework and deduces lessons from this methodology for contemporary biblical exegetes. In the process, the study points out some flaws in contemporary interpretative practices and suggests how Christians can avoid these flaws.
\end{abstract}

Correspondence: Isaac Boaheng Email: revisaacboaheng@gmail. com

Manuscript

Received 25th May 2020,

Accepted 31st August 2020,

Published online 2nd September 2020.

Keywords: Authority, Exegesis, Experience, Wesleyan Quadrilateral, Reason, Scripture, Tradition

\section{INTRODUCTION:}

\section{The Historical Development of the Wesleyan Quadrilateral}

The context within which Wesley's exegetical thought developed is significant to the current study. The Protestant Reformation and its associated issues played a very crucial role in forming the historical setting into which Wesley was born. The Reformation era saw heated debates between the Reformers and the Roman Catholic Church over the source(s) of authority for religious ethics and other issues. The question as to the source of authority was answered from two extreme viewpoints. Key players of the Protestant Reformation, including, Martin Luther, John Calvin and Ulrich Zwingli accepted only Scripture as authoritative for decisions regarding Christian beliefs, values, and practices. ${ }^{2}$ This position stood in opposition to Roman Catholic position that Church tradition and Church magisterial authority are as equally authoritative as Scripture.

The 18th century Enlightenment that followed the Reformation led to various developments in biblical exegesis (that is, the interpretation of a biblical text within its original socio-cultural context and to deduce contemporary applications from it). The Enlightenment emphasized the need to appeal to reason and scientific explanation in British culture. During this period, natural processes and independent human thought replaced the relevance of divine revelation, as theological exegesis gave way to philosophical exegesis. Biblical exegesis was informed by human scientific advances and reasoning rather than the traditional doctrine of divine revelation of Scripture. Christian scholars began to raise issues concerning the validity of using reason as a foundation for making religious decisions.

In the midst of the debate the Anglican Church chose a middle way between the priority of Scripture, reflective of the Protestant tradition, and tradition of the church, characteristic of the Roman Church. ${ }^{3}$ Thus, the Anglican regarded the trio of Scripture, tradition, and reason as authoritative rather than the one-sided approach of biblicism, traditionalism, or rationalism. ${ }^{4}$ This position afforded Anglicanism the opportunity not only to avoid the two extremes of Catholicism and Protestantism but also to accommodate the views of the Enlightenment.

\footnotetext{
Donald A. D. Thorsen, "Sola Scriptura and The Wesleyan Quadrilateral” in Wesleyan Theological Journal Vol. 41, No. 2 (2006):7-27, 7.

Thorsen, "Sola Scriptura and The Wesleyan Quadrilateral", 7-8.

4 John Wesley, The Works of John Wesley Volume 12: Doctrinal and Controversial Treatises edited by Randy L. Maddox

(Nashville: Abingdon Press, 2012), 8.
} 
The situation above forms the broader theological context into which Wesley was born. Following the Anglican tradition, Wesley considered Scripture, tradition, and reason as authoritative for religious decisions and practice. ${ }^{5}$ However, he went a step further to add experience as an authority in matters of religious ethics.. The introduction of extra biblical authorities in Wesley's theological method was not intended to evolve any new method of theologising. After all, Wesley affirmed historic, biblical Christianity. Wesley intended to give primacy to Scripture and use the extra biblical authorities to organize, illumine, and apply Scripture. ${ }^{6}$ This approach to theology proved more satisfactory than does the authoritarian traditionalism of Catholicism or rationalistic Biblicism of fundamentalists. By Biblicism, we refer to the over-rigid adherence to certain biblical texts at the expense of context or the literal approach to biblical interpretation which regards the Bible as a moral text book and use it out of context.

Wesley's four foundations for biblical exegesis (namely, Scripture, reason, experience and tradition) have been referred to as the Wesleyan Quadrilateral or Methodist Quadrilateral, an expression which Wesley himself did not use. The expression emerged from attempts to summarize the Wesleyan fourfold principle for theological formulation. Scholars trace the conceptual development of the Wesleyan Quadrilateral to modern critical Wesley Studies that started in the 1960s. The idea of the Wesleyan Quadrilateral was anticipated in Colin W. Williams' 1960 publication on Wesleyan theology, ${ }^{7}$ a work which was prompted by Williams' engagement in various phases of the ecumenical movement. From the perspective of the ecumenical movement, Williams attempted to comprehend Wesley's view on authority as related to the authority of various confessional traditions. He discussed how Wesley used Scripture, tradition, reason and experience interactively to arrive at theological and ethical conclusions.

Though Williams played a key role in Wesleyan studies, it was Albert Outler, a Methodist scholar, who later coined this term "Wesleyan Quadrilateral" as his summary of Wesley's thought on the theological and ecclesiastical discussion of contemporary issues facing Christianity. ${ }^{8}$ Outler used the expression "quadrilateral" to illustrate how Wesley employed Scripture, tradition, reason, and experience in theological formulations and developments. ${ }^{9}$ The Methodist Quadrilateral views a four-point method of understanding God's nature, purpose, and will with Scripture, tradition, experience and reason as partners. Wesley paid more attention to the beliefs and practices of the Church than formulating a theology of his beliefs. ${ }^{10}$ Therefore, Outler's term is intended "to emphasize that Wesley relied more on 'standards of doctrine' in his theological approach than on theological Systems or juridical Confessions of Faith."11

The idea of a quadrilateral might have been borrowed from ancient sources. The Wesleyan Quadrilateral relates to early patristic literature which teaches that the church can stand united and secure if Christian teaching is formulated within a fourfold fortress, like the four "fortress cities" of Lombardy. ${ }^{12}$ The Lambeth Quadrilateral of 1888, which derives from this ancient document, gave four essentials for reuniting the Christian Church from the Anglican understanding. ${ }^{13}$ This Quadrilateral became popular among all Christian denominations. From this fact, it seems that Outler dwelt heavily on the historical background of the terminology "quadrilateral" than the mere fact that he wanted a four-sided figure. Unfortunately, people misconstrued its meaning as intended by Outler. For this reason, Outler later came to regret this phraseology. He stated, "The term 'quadrilateral' does not occur in Wesley-and more than once, I have regretted having coined it for contemporary use, since it has been so widely misconstrued." ${ }^{14}$

Though Wesley did not comprehensively develop the concept of a "quadrilateral," the idea is deducible from at least two titles from his writings. First, Wesley titled his doctrinal paper on Original Sin "The Doctrine of Original Sin, according to Scripture, Reason, and Experience."15 In this statement are found three aspects of the quadrilateral, namely, Scripture, reason, and experience. Second, the preface to the first collection of Wesley's works gives us a clue

\footnotetext{
Thorsen, "Sola Scriptura and The Wesleyan Quadrilateral", 7.

6 Donald A. D. Thorsen, The Wesleyan quadrilateral: Scripture, Tradition, Reason \& Experience as a Model of Evangelical Theology (Lexington, KY: Emeth Press, 1990), 125.

7 Colin W. Williams, John Wesley's Theology Today: A Study of the Wesleyan Tradition in the Light of Current Theological Dialogue (Nashville: Abingdon Press, 1960), 23-38.

8 See Albert Outler, "The Wesleyan Quadrilateral in John Wesley" in Doctrine and Theology in the United Methodist Church, ed. Thomas A. Langford (Eastbourne: Kingsway Publications,1991), 75-88. See also Thorsen, “Sola Scriptura and The Wesleyan Quadrilateral”, 18.

9 Beside Outler's use of a quadrilateral, different scholars have used different figures to illustrate Wesley's concept pictorially. Timothy L. Smith's pictures Wesley's concept as of the three-legged stool: Holy Scripture as the floor upon which the stool stands, and tradition, reason, and experience as the legs standing upon the floor and supporting Christian doctrine, which is represented by the seat. See Timothy L. Smith, "John Wesley and the Wholeness of Scripture," The Preacher's Magazine, 61:4 (1986), 12-15, 55-57.

10 Thorsen, "Sola Scriptura and The Wesleyan Quadrilateral", 19.

11 Maddox as cited in Thorsen, "Sola Scriptura and The Wesleyan Quadrilateral", 18.

12 Thorsen, "Sola Scriptura and The Wesleyan Quadrilateral", 20.

13 Ibid.

14 Albert Outler, “The Wesleyan Quadrilateral in Wesley” in Wesleyan Theological Journal Volume 20, No. 1 (1985): 7-18, 16. For further analysis of the issue consult Daniel Castelo (ed.), Embodying Wesley's Catholic Spirit (Eugene, OR: Wipf \& Stock Publishers, 2017$), 46$.

${ }_{15}$ John Wesley, "The Doctrine of Original Sin, according to Scripture, Reason, and Experience" in Thomas Jackson, ed., The Works of the Reverend John Wesley, A.M. [14 volumes; London: Wesleyan Conference Office, 1872], 9:191.
} 
to his emphasis on Scripture, reason and tradition. ${ }^{16}$ These two statements therefore give the fourfold quadrilateral of scripture, tradition, reason, and experience as a conceptual framework implied in Wesley's works.

The use of the word "quadrilateral" may be misleading as it most likely carries the notion that each of the four components has equal ability and authority in providing theology. The Wesleyan Quadrilateral should not be viewed as the "three-legged stool" of Roman Catholicism. According to Catholic faith there are three equal sources of authority, namely, the magisterium, Scripture, and tradition (as noted earlier). For Wesley, Scripture alone can be regarded as the infallible source of truth. Therefore, he used the other three components as tools for confirming one's understanding of Scripture. Wesley's original appeal is to Scripture and "only derivatively to tradition, reason, and experience." ${ }^{17}$

\section{The Four Sources of Authority (The Wesleyan Quadrilateral)}

The Wesleyan Quadrilateral states that every sound exegesis must rest on the foundations of a quartet of Scripture, reason, experience and tradition. In this section, the study takes a look at each of these sources of authority in religious matters as set forth by Wesley and Wesleyan scholars.

Fig.1: A diagram depicting the Wesleyan Quadrilateral

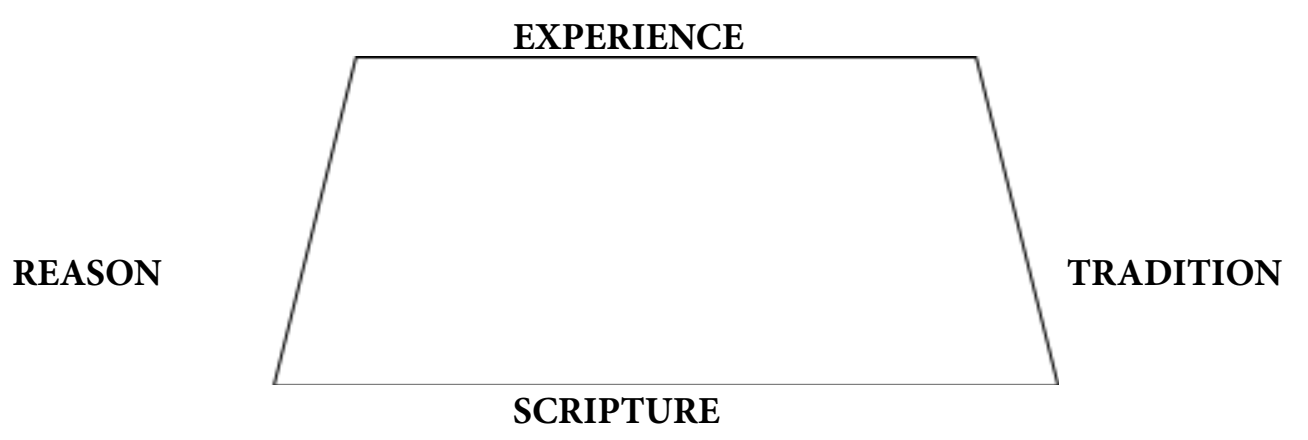

\section{Scripture}

Wesley emphasized the priority and finality of the authority of Scripture in the derivation of theology. He received the Scripture as God's revelation to humanity and regarded it as the highest authority just as the supreme court has the highest judicial authority. ${ }^{18}$ Scripture refers to the sixty-six books of the Protestant canon. It is the text of the Bible which has come from God's self-revelation as sufficient to disclose God's will to the faithful reader. Wesley contended that Scripture is the foremost authority and has the only yardstick against which all other truth is to be evaluated. The training he received from his dissenting parents most likely contributed to his emphasis on the biblical authority. For Wesley, Scripture is meant to facilitate one's understanding of God's will, way and nature. Wesley believed that the Bible is without errors. The Holy Spirit gave divine guidance to those who received special revelation from God to write books of the Bible and so there can be no error in the Scriptures. He believed that if the biblical authors erred in one place, then the Bible cannot be reliable because one would not know where else they erred: "If there is any mistake in the Bible, there may well be a thousand. If there be one falsehood in that book, it does not come from the God of truth."19

At about 27 years (in 1730), Wesley was determined to become "a man of one book", that is, the Holy Bible. To say that Wesley was a man of one book is not to say that he was ignorant of other religious and non-religious books or that only the Bible was useful to him. Rather, it means that for Wesley, all other books must be read and understood in relation to the Bible. As a man of the Bible, Wesley developed a lifelong attitude of studying Scriptures every morning. Like other Protestant theologians, his faith was built on what the Bible contained and what could be proven by the Bible. ${ }^{20}$ That is the reason why Wesley could say, "I allow no other rule, whether of faith or practice, than the Holy Scriptures." ${ }^{21}$ Elsewhere he advised others, "be not wise above what is written. Enjoin nothing that the Bible does not clearly enjoin. Forbid nothing that it does not clearly forbid." 22

Wesley's priority for Scripture is evident throughout his work. In his works, one comes across comments like "There is no passage in all the Word of God which affirms any such thing"; "But we can by no means agree with this. We

\footnotetext{
${ }^{16}$ John Emory, The Works of the late Reverend John Wesley (New York: B. Waugh \& T. Mason, 1835), x.

17 Thomas C. Oden, John Wesley's Scriptural Christianity: A Plain Exposition of His Teaching on Christian Doctrine (Grand Rapids, MI: Zondervan Publishing House, 1994), 55.

18 The Methodist Church Ghana, Local Preachers' Manual Part II, revised edition (NP:NP, 2013), 189.

19 Clark H. Pinnock, Biblical Revelation: The Foundation of Christian Theology (Chicago: Moody Press, 1971), 73.

20 Oden, John Wesley's Scriptural Christianity, 56.

${ }^{21}$ Ibid.

22 Ibid.
} 
find no authority for it in the holy writ"; "And for the decision of the matter I appeal to your conscience, guided by the Word of God."23 He also wrote "We believe, indeed, that all Scripture is given by the inspiration of God; and herein we are distinguished from Jews, Turks, and Infidels. We believe the written word of God to be the only and sufficient rule both of Christian faith and practice; and herein we are fundamentally distinguished from those of the Romish Church." ${ }^{24}$

In his contention for the primacy of Scripture in theological formulation, Wesley did not deny the human agency in the writing, transmission and hearing of Scripture. He stressed the importance of the Holy Spirit in understanding Scripture. Scripture, according to Wesley can be understood only through the illumination of the Spirit because he (the Spirit) is the author and hence the best interpreter of the Scriptures. ${ }^{25}$ Wesley therefore believed the divine inspiration of the Scripture. The term "inspiration" has to do with the reception of the divine message and the accuracy with which it is transcribed. Geisler and $\mathrm{Nix}^{26}$ make two key points about the inspiration of Scriptures. First, inspiration deals with the objective text of the Bible, not the objective intention of the biblical writer. Second, it is whole of the Bible which is God's word, not part of it. For Wesley, "Scripture was the inspired, authoritative, and trustworthy revelation of God. One was to study it inductively and critically, relative to his eighteenth-century understanding of biblical hermeneutics." ${ }^{27}$ With the belief that the inspiration of Scripture is only applicable to the original languages, Wesley encouraged the reading of the Bible in its original languages of Hebrew, Greek and Aramaic.

\section{Tradition}

Generally speaking, church tradition refers to a denomination's theological heritage expressed in their publications, faith statements, and life patterns and doctrinal formulations. However, in the context of Wesleyan Theology, tradition refers to the accumulated beliefs and practices of the Christian church down through the centuries. Wesley recognized the importance of church history, arguing that every faithful biblical interpretation must be historically-informed. By referring to historic interpretations Wesley sought to avoid repeating wrong interpretations of the past in his theological analysis.

Though he claimed to be a man of only one book, Wesley read voraciously and in all genres. The works of the early Christian Fathers became very useful to his understanding of theology. He read extensively the works of the early Church Fathers such as Ignatius, Tertullian, Polycarp, Irenaeus, Tertullian, Cyprian, Chrysostom, Basil, Ephrem Syrus, and Macarius. Wesley learned both from the Western and Eastern Church Fathers. He learned a lot from the Fathers of the Eastern Church concerning salvation and restoration of humanity. Throughout his works, Wesley made references to many writings that have influenced thought and ministry. He drew from a wide range of publications from the Patristic times to the Reformation.

Wesley did not consider tradition as inspired, yet, he often used theological sources (works of other people) to support his interpretation of Scripture. For Wesley, the exegetical works of the Church Fathers are very useful in "the explication of a doctrine that is not sufficiently explained, or for confirmation of a doctrine generally received." ${ }^{28}$ His interest in the works of the early Church lies in the fact that he considered this Church to have had the purest form of Christianity. Wesley wrote, "We prove the doctrines we preach by Scripture and reason, and if need be, by antiquity." Antiquity, in this case, refers to "the religion of the primitive church, of the whole church in the past ages," with special reference to Church Father like Ignatius, Clement, Tertullian, Polycarp, Irenaeus, Origen, Tertullian, Cyprian, Chrysostom, Basil, Ephrem Syrus, and Macarius. ${ }^{29} \mathrm{He}$ considered the Fathers as most authentic commentators of the Bible, as people who were very close to the events recorded in the Bible and people led by the Spirit to explain Scripture. ${ }^{30}$ He reaffirmed this view in a letter late in his life: "I regard no authority but those of the Ante-Nicene Fathers; nor any of them in opposition to Scripture."31

Church traditions also include the proceedings of the Ecumenical Councils especially those of the first four centuries. The various Church creeds including the Apostle's Creed, the Nicene Creed, the Athanasius Creed, among others, form part of the tradition of the Christian Church. The controversies and the struggles the early Church Fathers had to go through to make doctrinal decisions on issues such as the Trinity, the deity of Christ and the personhood of the Holy Spirit point to the fact that Scripture does not give all the answers to all the questions. Scripture must therefore not be regarded as a solution book where people can run to for solutions to their challenges.

23 Alice Russie, The Essential Works of John Wesley (Ohio: Barbour Publishing Inc, 2011), 13.

24 Alan P.F. Sell, David J. Hall, Ian Sellers (eds.), Protestant Nonconformist Texts Vol. 2: The Eighteenth Century (Oregon, OR: Wipf \& Stock Publishers, 2015), 117.

25 Oden, John Wesley's Scriptural Christianity, 58.

${ }_{26}$ Norman L. Geisler and William E. Nix, A general introduction to the Bible (revised edition) (Chicago, IL: Moody Press, 1968$), 36$.

27 Thorsen, "Sola Scriptura and the Wesleyan Quadrilateral", 21.

28 Oden, John Wesley's Scriptural Christianity, 66-67.

29 Ibid, 65.

30 Ibid, 66.

31 John Telford (ed.), The Letters of the Rev. John Wesley vol. 7 (London: Epworth Press, 1960), 106. 
Tradition functions as a valuable complement to Scripture. Therefore, the writings of the Church Fathers are regarded as theologically suitable for instruction if studied in conjunction with the Scriptures. Outler has noted that, "For Wesley, the Christian tradition was more than a curiosity or a source for illustrative material. It was a living spring of Christian insight. Reading Wesley against his sources amounts to an eccentric excursion through the length and breadth of the history of Christ thought." ${ }^{32}$ On the relation of Scripture and tradition Wesley wrote: "The Scriptures are a complete rule of faith and practice; and they are clear in all necessary points. And yet their clearness does not prove that they need not be explained; nor their completeness, that they need not be enforced." ${ }^{33}$ He stated further "The esteeming the writings of the first three centuries, not equally with, but next to, the Scripture, never carried any man yet into dangerous errors, nor probably ever will." ${ }^{34} \mathrm{He}$ also asserted "In all cases, the Church is to be judged by the Scripture, not the Scripture by the Church. And Scripture is the best expounder of Scripture. The best way, therefore, to understand it, is carefully to compare Scripture with Scripture, and thereby learn the true meaning of it."35

Tradition provides us with the wisdom of the past and promotes accountability in discipleship. It draws attention to the fact that one has "a great cloud of witnesses" who have gone ahead of him or her (cf. Heb. 12:1). The witnesses of the past serve to guide contemporary believers in their theological discourses and practice. Whenever one reads and interprets the Bible, he or she joins others in reading and trying to make meaning out of it. This does not matter even if one reads the Bible alone because the person will still influence other believers through his or her thoughts and at the same time what he or she is reading is also shaped by others, such as translators and scholars of the text, Bible expositors and commentators. Church tradition regarding issues such as biblical sacraments of the Eucharist, Christian baptism, the practice of foot-washing, are received as means of spiritual renewal; how the church has dealt with polygamy and polygyny can go a long way to inform decisions of the contemporary church. By recognizing faith traditions, one acknowledges the community of believers and the tradition that has shaped this believing community.

This principle is very crucial as it helps the reader to appreciate the wrong conceptions which have led to misunderstandings of God's word. Therefore, it equips the believer to be in a better. Church tradition tells us that we are not the first believers on earth, therefore difficulties in theology that are encountered today have been encountered long before by our forebears. Knowing how others have handled an issue will go a long way to help one to handle that issue or a similar one effectively. Yet, the Wesleyan Quadrilateral paradigm acknowledges that not all Christian traditions are in accordance with God's will and purpose. This danger needs to be checked by interpreting tradition in the light of every succeeding age and each new cultural setting. It is for this reason why the contemporary exegete (or interpreter) needs a proper understanding of the tradition of the Church.

\section{Reason}

Reason is defined as the ability of the human mind to think, comprehend and make a logical judgment. ${ }^{36}$ It is "the use of the power of thought and laws of logic to make mental judgments." ${ }^{37}$ The role of reason in religion dates back to ancient Greek philosophers who considered it as a masterful principle of Creation. This aspect of the quadrilateral is based on the assumption that the human mind is endowed with the ability to understand God's revealed truth. ${ }^{38}$ While considering Scripture to be of prime importance, Wesley recognized the immense value of philosophy and the sciences, and taught other about the worth of these disciplines.

Reason is so important that without it, information derived from Scripture, tradition, and experience cannot be formulated and assimilated. ${ }^{19}$ Human reason is essential to everything humans do in life, not just religious matters. Without the ability to reason, theological and ethical discourses would be impossible. Contradictions and illogical deduction could not be detected if humans had no power to reason. Without reasoning there is no basis to either prove or disprove any proposition..$^{39}$ As a religion of logic and non-contradictions, Christianity must be rational, plain and intelligible. Therefore, any proposition that departs from true genuine reason automatically departs from Christianity. Wesley's acknowledgment of rationality as normative can be seen in the following words: "It is a fundamental principle with us [Methodists] that to renounce reason is to renounce religion, that religion and reason go hand in hand, and that all irrational religion is false religion." ${ }^{40}$ Throughout his life, Wesley was a disciple of Locke and Aldrich. From the Wesleyan perspective human intuition is a "spiritual sensorium" in the human mind through which the Holy Spirit gets

32 Outler, "The Wesleyan Quadrilateral in Wesley", 14.

33 As cited in Oden, John Wesley's Scriptural Christianity, 67.

34 Ibid.

35 Thomas Jackson (ed.), The Works of John Wesley vol. 10(Grand Rapids, MI: Baker Book House, 1979 ), 142.

36 Donald K. McKim, The Westminster Dictionary of Theological Terms [WDTT] second edition revised and expanded (Louisville, KY: Westminster John Knox Press, 2014), 263.

37 McKim, The Westminster Dictionary of Theological Terms, 263.

38 The Wesleyan framework assumes faith is the necessary antecedent to reason as a source of theology.

39 Oden, John Wesley's Scriptural Christianity, 71.

40 Thorsen, The Wesleyan quadrilateral: Scripture, Tradition, Reason \& Experience as a Model of Evangelical Theology, 169. 
access into the human soul and spirit. ${ }^{41}$

Wesley engaged in a two-fold battle against "unreasonable charismatic enthusiasts who overstressed emotive spirituality" on one hand and "excessive rationalists who wanted to impose hyperskeptical criteria on the inquiry into the Christian faith." ${ }^{\prime 2}$ The unreasonable charismatic enthusiasts regard reason as contrary to religion and thus substitute their own emotions and imaginations (for the written word) for rational analysis and the reliable revelation of God respectively. One must be careful not to exalt reason to the position of making it the ultimate judge of revelation.

Reason is the consequence of the imago Dei, the fact that God created humans in his own image. As a constitutional element of being human, reason was regarded to be a unique gift from God to mankind, separating us from the beasts. ${ }^{17}$ It is a God-given gift that makes one capable of interpreting God's word, tradition, and experience in light of the world in which one finds himself or herself. God does not therefore require us to turn our brains off in order to have faith or to understand the Bible. God wants spiritual intellectuals. Although Scripture is the first and most important factor in its understanding, God gave humans intellectual abilities which must also be utilized. Reason, however, should not be disconnected from the guidance of the Holy Spirit. The Holy Spirit must always be the believer's guide. For Wesley, faith does not come from reason; yet, with impartial reason, one can appreciate the new birth, inward holiness, and outward holiness, all of which require faith.

\section{Experience}

Earlier it was noted that the Anglican Church of Wesley's day emphasized Scripture, tradition, and reason as three sources of theological reflection. Wesley added to these a fourth source of authority, namely, experience. In Wesley's thought experience has both empirical and experiential dimensions. The empirical knowledge of experience is concrete in nature, perceived by means of the natural senses, particularly by observation and experimentation. Experiential knowledge of experience is derived from personal or interpersonal understanding and insights, perceived by the "spiritual senses." The experiential aspect of religious faith was to ensure that Christianity cultivates the vitality of a personal encounter with God through Jesus (the Saviour) rather than spiritually lifeless orthodoxy. Yet, Wesley acknowledged the limitations of the authority derived from experience. The individualistic nature of religious experience could easily evolve in misinterpretation of its meaning. Wesley dealt with this shortcoming by stressing the need for religious experience to be vetted for its faithfulness to Scripture.

For Wesley, there can be no reasonable assurance of religion without personal experience. Experience has to do with one's own personal experience with God. It gives evidence to it on a personal level and provides the validation and context of the other three sections of the Methodist Quadrilateral. One's practical experience with the Holy Spirit leading to the indwelling of the Spirit, provides authentication of God's presence in the world and in our individual lives. The experiential nature of Wesley's theological thought has been capitalised by African Penteco-Charismatics. These churches consciously emphasize the experience of the work of the Holy Spirit in the believer's life. In the light of the Wesleyan Quadrilateral, one has to be cautious how he or she relies on experience in making theological formulations.

\section{The Wesleyan Quadrilateral and Sola Scriptura}

Too often people are tempted to consider the fourfold Wesleyan principle as contradictory to the Protestant Reformation principle of Sola Scriptura (that is, the idea that scripture alone as the source of authority for faith and practice). But a careful consideration shows that the two principles are complementary rather than contradictory. Both principles rely on a critical understanding and dynamic application of biblical and historical Christian beliefs, values, and practices to contemporary situations. The idea of contradiction comes in when one downplays "the multifaceted dimensions of Sola Scriptura" and/or "the primacy of scriptural authority in the quadrilateral." ${ }^{43}$ A deeper study shows that the Wesleyan Quadrilateral has the Protestant watchwords of Sola Fide and Sola Scriptura at its heart. ${ }^{44}$ The Wesleyan approach does not in any way ignore the primacy of Scripture. Similarly, the exegetical principles employed by Sola Scriptura in no way ignore the place of Church tradition, experience and reason. For instance, while Calvin stated that "Scripture is needed as guide and teacher for anyone who would come to God the Creator" he also affirmed that Scripture must be confirmed by the witness of the Holy Spirit and by how some traditions. ${ }^{45}$ In his he captions one of his chapters in Institutes of the Christian Religion he states that: "So far as human reason goes, sufficiently firm proofs are at hand to establish the credibility of Scripture" and argued for the place of reason in theological formulations. ${ }^{46}$

\footnotetext{
41 Outler, “The Wesleyan Quadrilateral in Wesley", 15.

42 Oden, John Wesley's Scriptural Christianity, 72.

43 Thorsen, "Sola Scriptura and The Wesleyan Quadrilateral", 8.

44 See Thorsen, "Sola Scriptura and The Wesleyan Quadrilateral", 19.

45 Nathan Crawford (ed.), The Continuing Relevance of Wesleyan Theology: Essays in Honor of Laurence W. Wood (Eugene, OR: Pickwick Publications, 2011), 204.

46 See Donald K. McKim (ed.), Calvin’s Institutes: Abridged Edition (Louisville: Westminster John Knox Press, 2000), 12.
} 
Alister McGrath after studying Reformation literature observes as follows: "Although it is often suggested that the Reformers had no place for tradition in their theological deliberations, this judgment is clearly incorrect. While the notion of tradition as an extra-scriptural source of revelation is excluded, the classic concept of tradition as a particular way of reading and interpreting Scripture is retained." ${ }^{47}$ Thus, it is best to consider sola scriptura and the Wesleyan quadrilateral as complementary principles of religious authority to matter of beliefs, values, and practices.

The Protestant emphasis on Sola Scriptura was a reaction to the extreme Catholic emphasis on their religious traditions passed on from one generation to the other through the priesthood and papacy. It seems that the Protestant reaction was equally extreme because even though the Scripture is the final authority for making Christian decisions, it does not touch on all issues especially those emerging from the modern world. Issues of over-population of the world, euthanasia, modern ways of birth control and others were not probably present in biblical times. Besides, there are certain issues the Bible does not touch because even though they existed in biblical times, they were not found among the biblical people. Therefore, to use the term Sola Scriptura to mean that the Bible alone can be used to answer all questions confronting humanity is unacceptable. Wesley contends that the concept of "Scripture alone" means no more or less than the fact that the Scriptures are the primary source (not the only) source of authority for making Christian decisions. Thus, Wesley believed that while Scripture alone is the final source of Christian doctrine, tradition, reason and experience have supporting function.

\section{Implications for Contemporary Biblical Exegesis}

Summing up, Scripture is always interpreted through the lenses of historical, literary, and contextual framework through a dialogue that exists within an interpretive framework of tradition, reason, and experience. Properly understood, the Wesleyan quadrilateral gives the right connection between the word of God and the reader's world. For contemporary exegetes, there is the need to establish the biblical basis for every ethic one deduces from any text. Like Wesley, one needs to make Scripture the primary source of religious authority. To know what God says one has to turn to the Scripture. In our theological inquiry one needs to ask questions like: How is this passage similar to or different from other passages of Scripture? Is this text based on another biblical text? If there is an intertextual connection, what was the original context for the other Scripture passage? The point so far is that anything that contradicts Scripture is unacceptable in God's sight.

Some people argue that the interpretations of our forefathers are of no value to us because they misunderstood God's word and therefore got it all wrong. They argue that if one factors past interpretation in our theology then he or she is just repeating their thought without allowing God to speak to us. ${ }^{48}$ The argument continues that it is wrong to use commentaries written by others in our theologizing. It is asked: Is Augustine, Calvin or Wesley not a human being just like us? Are we not in a better position to do better interpretation than these people since we live in a better world than theirs? Why then should we rely on what he wrote? We admit that people of our generation can be better than our forebears. However, this is only possible if we stand on the shoulders of the giants of the past. That is to say our interpretation becomes better only when we build on the foundations laid down in the past. In respect of tradition the interpreter may ask: From what tradition(s) (Jewish, pagan, other) did this text emerge? What have other people said about this text? How does this text agree or contradict your own church's traditions?

Reason tests the congruence of the witness of the Christian church with Scripture and relates this witness to the entirety of human knowledge, experience, and service. For Wesley theological ideas are expected to collaborate with what is rational and conceptual to human intelligence. The reasoning process draws from areas such as the sciences, philosophy, social sciences, and culture. It is important to state that although the Bible teaches the truth, it does not teach all the truth. Said differently, all that the Bible teaches is true, yet it is not all that is true that the Bible teaches. Rather than teaching us all that we want to know, the Bible teaches us all that God wanted us to know so that we would be saved.

The Quadrilateral tasks us to consider the impact Science may have on the interpretation of scripture. A coherent Christian interpretation should attempt to bring together the "the book of nature", that is Science (Psalm 19:16, Rom. 1:19-20) and "the book of Scripture" (Psalm 19:7-10, 2 Tim. 2:15-17). What the Bible actually teaches must be in perfect harmony with every truth revealed by Science. Both Scripture and nature were authored by the same true noncontradicting God. Therefore, when both books are correctly interpreted, according to appropriate principles apparent contradictions would be resolved. One must acknowledge that all truth is God's truth. Any true knowledge obtained from nature, through Science or any other field, cannot contradict any true knowledge obtained from a true interpretation of Scripture. Contradiction may set in only when either scientific data or Scripture or both are misinterpreted. The exegete must therefore not regard Science and religion as enemies. He or she must accept any scientific discovery that is confirmed by Scripture and investigate those that contradict scripture, bearing in mind that the Bible does not make any mistake but interpreters do. The interpreter may ask: How does this logic influence my thoughts? Does Science or

\footnotetext{
47 Alister McGrath, The Genesis of Doctrine: A Study in the Foundations of Doctrinal Criticism (Oxford: Basil Blackwell, 1990$), 130$.

48 A personal conversation with some contemporary pastors.
} 
philosophy confirm this?

There are great lessons for those who judge Scripture by experience or test the validity of its interpretation based on experience. People deduce from Scripture that it is not sinful to stake lotto once the lotto numbers are given by socalled prophets of God. Eventually the numbers are given and their followers claim win huge sums after staking. There are others who are abused sexually or in other ways in the name of receiving help from the so-called pastors to overcome one problem or the other. It is not uncommon to read of "pastors" who sleep with women who come to them to seek help. The issue of "spiritual bathing/cleansing" where religious leaders take people (even of the opposite sex) to the stream to bath them as means of cleansing them is also not uncommon in African Christianity. Most of the people who fall prey to religious leader in this regard are those who judge the authenticity of Christian ministry by experience. Those who experience this kind of ministry sometimes argue that the practice is ethical because of their personal experiences.

Contrary to the thought that the validity of a religious practice depends on religious experience, the Wesleyan Quadrilateral stresses that experience serves in confirming the truth revealed by Scripture rather than validating what is religiously or ethically acceptable or not. This means that it is what Scripture affirms that one can seek to experience. To experience something that has no biblical foundation is unacceptable. Against this backdrop, the present author contends that Christians who do not experience the scriptural message should question their interpretation of the Bible. Since religious experience is to be judged in the light of Scripture (and not the other way round), one has to be cautious about the kind of Christianity that is built on experiences and not on the Word of God. Miraculous experiences must not be considered as right simply because one has experienced it. As a matter of fact, the devil also performs miracles and so if miracles become the yardstick for determining what is right or wrong then, one is bound to land into trouble. The writer therefore agrees with Wesley that every experience that contradicts Scripture must be rejected. There is a great lesson for those who approach Christianity from the problem-solving perspective, that is, those whose aim in Christian ministry is to find solutions to their existential challenges at the expense of spiritual growth. This form of Christianity, which is common among contemporary believers, must be checked.

The exegete, in considering experience, may ask: What have I learned from my life? How does my experience of God's grace help me think about what I believe? What experience was this passage originally for or about? In addition, there is the need to consider contextual issues. Outler is therefore right to observe that, "Neither the Wesley theology, nor his methods are simple panaceas. ... They call for imaginative updating in the new world cultural contexts .... Wesley's vision of Christian existence has to be reconceived and transvalued so that it can be as relevant" 49 today as it was his time. To do this, the exegete must refocus these principles in a balanced manner, "deeply immersed in Scripture, ... truly respectful of the Christian wisdom of past ages, honestly open to the disciplines of critical reason and eagerly alert to the fire and flame of grace." ${ }^{50}$

\section{CONCLUSION}

The Wesleyan Quadrilateral seeks to display the principle of the interdependence of all four authorities under the primacy of Scripture. Tradition is the collective wisdom of the church in interpreting Scripture. Experience is to the person what tradition is to the whole Christian community. Reason is the critical discipline used in judging the credibility of all interpretations. Tradition, experience, reason are ways of understanding and interpreting the Scripture. Church Tradition, personal experience and logical reasoning must be scrutinized in light of Scriptures. Scripture is our only true source, while tradition, reason, and experience work to help us understand Scripture. Wesley emphasized the priority and finality of the authority of Scripture in the derivation of theology. All other sources are viewed as less authoritative than it. Therefore, all theological formulations of the Christian church must be revealed in Scripture, illumined by tradition, made vivid in personal experience and endorsed by reason. Finally, since all theological formulations are contextually informed, it is important to take into consideration the context to which one is applying the Scripture so that one's theology does not only become biblically grounded but also contextually relevant.

\section{BIBLIOGRAPHY}

Calvin, John. Institutes of the Christian Religion, 2 vols. in 1, translated by Ford Lewis Battles. Philadelphia: Westminster Press, 1960.

Castelo, Daniel, ed. Embodying Wesley's Catholic Spirit. Eugene, OR: Wipf \& Stock Publishers, 2017.

Crawford, Nathan, ed. The Continuing Relevance of Wesleyan Theology: Essays in Honor of Laurence W. Wood. Eugene, OR: Pickwick Publications, 2011.

Emory, John. The Works of the late Reverend John Wesley. New York: B. Waugh \& T. Mason, 1835.

\footnotetext{
${ }_{49}$ Outler, "The Wesleyan Quadrilateral in Wesley", 17.

${ }^{50}$ Ibid.
} 
Jackson, Thomas (ed.). The Works of the Reverend John Wesley, A.M. 14 volumes; London: Wesleyan Conference Office, 1872.

Geisler, Norman L. and William E. Nix, A general introduction to the Bible. revised edition. Chicago, IL: Moody Press, 1968.

Jackson, Thomas (ed.). The Works of John Wesley vol. 10. Grand Rapids, MI: Baker Book House, 1979.

McKim, Donald K., ed. Calvin's Institutes: Abridged Edition. Louisville, KY: Westminster John Knox Press, 2000. The Westminster Dictionary of Theological Terms. second edition revised and expanded. Louisville, KY: Westminster John Knox Press, 2014.

McGrath, Alister. The Genesis of Doctrine: A Study in the Foundations of Doctrinal Criticism. Oxford: Basil Blackwell, 1990.

Oden, Thomas C. John Wesley's Scriptural Christianity: A Plain Exposition of His Teaching on Christian Doctrine. Grand Rapids, MI: Zondervan Publishing House, 1994.

Outler, Albert. "The Wesleyan Quadrilateral in Wesley" in Wesleyan Theological Journal Volume 20, No. 1 (1985): 7-18. "The Wesleyan Quadrilateral in John Wesley" in Doctrine and Theology in the United Methodist Church, ed.

Thomas A. Langford. Eastbourne: Kingsway Publications,1991.

Pinnock, Clark H. Biblical Revelation: The Foundation of Christian Theology. Chicago: Moody Press, 1971.

Russie, Alice. The Essential Works of John Wesley (Ohio: Barbour Publishing Inc, 2011), 13.

Sell, Alan P.F., David J. Hall, Ilan Sellers (eds.), Protestant Nonconformist Texts Vol. 2: The Eighteenth Century. Oregon, OR: Wipf \& Stock Publishers, 2015.

Smith, Timothy L. "John Wesley and the Wholeness of Scripture," The Preacher's Magazine, 61:4 (1986).

Telford, John (ed.), The Letters of the Rev. John Wesley vol. 7. London: Epworth Press, 1960.

The Methodist Church Ghana, Local Preachers' Manual Part II, revised edition. NP:NP, 2013.

Thorsen, Donald A. D. The Wesleyan quadrilateral: Scripture, Tradition, Reason \& Experience as a Model of Evangelical Theology. Lexington, KY: Emeth Press, 1990.

"Sola Scriptura and The Wesleyan Quadrilateral" in Wesleyan Theological Journal Vol. 41, No. 2. (2006):7-27.

Wesley, John. The Works of John Wesley Volume 12: Doctrinal and Controversial Treatises edited by Randy L. Maddox. Nashville: Abingdon Press, 2012.

Williams, Colin W. John Wesley's Theology Today: A Study of the Wesleyan Tradition in the Light of Current Theological Dialogue. Nashville: Abingdon Press, 1960.

\section{ABOUT AUTHOR}

Isaac Boaheng is an ordained minister of the Methodist Church Ghana serving the Nkwabeng Circuit of the Sunyani diocese. He also serves as a Translator for the Bible Society of Ghana. Isaac holds a Master of Divinity degree from the Trinity Theological Seminary, Accra, Ghana and has research interest in Public Theology, Biblical Studies, and African Christianity. 